\title{
Mutants of Mycobacterium rhodochrous with Modified Patterns of $n$-Paraffin Utilization
}

\author{
By P. G. JENKINS, D. RABOIN AND F. MORAN \\ Société Internationale de Recherche BP, 28-Epernon, France
}

(Accepted for publication 4 April 1972)

\section{INTRODUCTION}

Mycobacterium species are capable of growth on individual $n$-paraffins as sole carbon sources (Foster, I962; Fredricks, 1967; Trust \& Millis, I970 $a$ ). $n$-Paraffins containing from Io to I 8 carbon atoms are utilized most frequently, but Foster (1962) has identified a number of strains of Mycobacterium from several species, which utilize $n$-paraffins over various different ranges of chain length. Some strains could grow on all $n$-paraffins from propane to hexadecane.

Hitherto, the elucidation of the degradative pathway for $n$-paraffins has been hampered by a lack of mutations specific for this pathway. Although $n$-paraffin metabolism generally proceeds via terminal oxidation to alcohol, aldehyde and monocarboxylic acid, which then undergoes $\beta$-oxidation, some aspects remain uncertain, in particular, whether an olefin is or is not an intermediate (Iizuki, Iida, Unami \& Hoshino, 1968).

We report here the isolation of mutant strains of Mycobacterium rhodochrous which have patterns of $n$-paraffin utilization different from that of the wild-type.

\section{METHODS}

The wild-type used was Mycobacterium rhodochrous B29, selected from soil on the basis of an ability to grow on the $n$-paraffins of kerosene (a mixture of $n$-paraffins in which hendecane, dodecane and tridecane predominate). The following minimal medium was used throughout: $\mathrm{KH}_{2} \mathrm{PO}_{4}, \mathrm{I} \cdot 36 \% ;\left(\mathrm{NH}_{4}\right)_{2} \mathrm{SO}_{4}, 0.2 \% ; \mathrm{MgSO}_{4} .7 \mathrm{H}_{2} \mathrm{O}, 0.02 \% ; \mathrm{FeSO}_{4}, 5 \times 10^{-5} \% ; \mathrm{KOH}$, $0 . \mathrm{II} \%, \mathrm{pH}$ adjusted to 6.2 with $\mathrm{KOH}$. Utilization of $n$-paraffins as carbon sources was tested at $30{ }^{\circ} \mathrm{C}$ on plates of this medium solidified with $\mathrm{I} \cdot 8 \%$ Difco Special Agar; previously autoclaved paraffin was homogenized in the molten medium with an Ultra-Turrax homogenizer at $20 \mathrm{mg} / \mathrm{ml}$, without emulsifier. Paraffins with from 8 to 28 carbon atoms were tested, and plates were inoculated by replica plating. The ability of alcohols, aldehydes and monocarboxylic acid to support growth was complicated by their somewhat toxic nature; they were therefore placed in central wells and allowed to diffuse through the agar.

Isolation of mutants. Mutants, obtained either spontaneously or by mutagen treatment, were isolated by the method of Davis (I949). An overnight culture of B29 was harvested, resuspended in buffer $\left(\mathrm{Na}_{2} \mathrm{HPO}_{4}, 0.7 \% ; \mathrm{KH}_{2} \mathrm{PO}_{4}, 0.3 \% ; \mathrm{NaCl}, 0.4 \%\right)$ and incubated with $N$-methyl- $N^{\prime}$ nitro- $N$-nitrosoguanidine $(500 \mu \mathrm{g} / \mathrm{ml})$ for $40 \mathrm{~min}$ at $30{ }^{\circ} \mathrm{C}$. This resulted in a $50 \%$ kill of the bacterial population. After washing, the cells were grown overnight in nutrient broth to allow the phenotypic expression of auxotrophy, washed again, resuspended in minimal medium containing $n$-octane ( $10 \mathrm{mg} / \mathrm{ml}$ ) and benzyl-penicillin (300 units $/ \mathrm{ml}$ ) and shaken at $30^{\circ} \mathrm{C}$ overnight. Mutants incapable of growing on $n$-octane were selected. Mutants unable to grow on other $n$-paraffins were obtained in a similar way. All 
mutants were plated on glucose-supplemented minimal medium to ensure that the inability to grow on $n$-paraffins was not due to an amino acid or other requirement.

Assay for n-octane hydroxylating activity. Batch cultures of $\mathrm{B} 29$ were grown at $30{ }^{\circ} \mathrm{C}$ to the late exponential phase on minimal medium (paraffins, when present supplied in the vapour phase) and centrifuged. The cells were thoroughly washed in cold $0.067 \mathrm{M}$-phosphate buffer, $\mathrm{pH} 7 \cdot 4$, and resuspended in buffer to a concentration of $0.5 \mathrm{~g}$ (wet wt)/ml and stored at $-10{ }^{\circ} \mathrm{C}$. Cells were disrupted with a Braun bead disintegrator, and the supernatant liquid obtained after centrifuging at $23000 \mathrm{~g}$ for $30 \mathrm{~min}$ was assayed for octane hydroxylase by the method of Cardini \& Jurtshuk (1970), protein being measured by the method of Lowry, Rosebrough, Farr \& Randall (195I). Octanol formed was extracted into butyl acetate and estimated by gas-liquid chromatography, using a $\mathrm{r} \cdot 80 \mathrm{~m}$ stainless steel column packed with I0 \% Carbowax $20 \mathrm{M}$-TPA (terephthalic acid terminated). The instrument was fitted with a flame ionization detector and the conditions were as follows: Temperatures - injection port, $250{ }^{\circ} \mathrm{C}$; flame ionization detector, $250{ }^{\circ} \mathrm{C}$. Gases - helium, $30 \mathrm{ml} / \mathrm{min}$; hydrogen, $40 \mathrm{ml} / \mathrm{min}$; air, $500 \mathrm{ml} / \mathrm{min}$. Column temperature programme - start $100{ }^{\circ} \mathrm{C} ; 2 \mathrm{~min}$ isothermal at $100{ }^{\circ} \mathrm{C}$, followed by programming at $15{ }^{\circ} \mathrm{C} / \mathrm{min}$ to $220^{\circ} \mathrm{C}$.

\section{RESULTS}

A number of different types of stable mutant were obtained, varying in their patterns of $n$-paraffin utilization as indicated in Table I. Mutants of type D were obtained from B29 at a particularly high frequency either spontaneously or after mutagen treatment and did not revert to the wild-type either spontaneously or following mutagen treatment. Mutants of types $\mathrm{C}, \mathrm{E}, \mathrm{F}$ and $\mathrm{G}$ were in general less stable, some of them tending to revert either to the wild-type or to a type $\mathrm{D}$ pattern. Type J mutants could utilize none of the $n$-paraffins. When strain M35, the only type A mutant obtained, was grown overnight in nutrient broth and plated on nutrient agar, $3 \%$ of the colonies examined were found to have undergone a further mutation to the type B pattern. Mutants of this type remained stable and could not be directly obtained from the wild-type.

The ability of the mutants to grow on various of the postulated intermediates of $n$-paraffin metabolism, viz. acetic, butyric, hexanoic, octanoic, nonanoic and decanoic acids, I-octanol and octanal, was tested. All these substrates served as sole carbon sources for the growth of mutant types A to I but none were utilized by type $\mathrm{J}$ mutants. The possibility that the mutants might be inhibited by $n$-paraffins was excluded by growing the mutants on glucose-supplemented minimal medium in the presence and absence of $n$-paraffins.

Measurement of the $n$-octane hydroxylating activity of cell-free extracts of B29 gave specific activity values (expressed as nmoles I-octanol formed $/ \mathrm{min} / \mathrm{mg}$ protein) of $\mathrm{I} \cdot \mathrm{I} 7$ in the case of $n$-octane-grown cells but less than 0.1 for those grown on glucose, ethanol or glycerol. Thus the enzyme system is inducible and, in this respect, it resembles the hydroxylating system found in Pseudomonas (McKenna \& Coon, 1970) and Corynebacterium (Cardini \& Jurtshuk, 1970). Furthermore, both $n$-nonane and $n$-decane functioned as inducers of $n$ octane hydroxylation, giving specific activities of 0.49 and 0.70 respectively. This may either indicate a specific $n$-octane hydroxylase with low specificity of induction, or a wide range $n$-paraffin hydroxylase which may be induced by any of its substrates.

The $n$-octane hydroxylating activity of strain M35, a type A mutant, was measured following growth on $n$-nonane and $n$-decane, since this strain is incapable of growth on $n$ octane. High specific activities were observed in both cases, values being $I_{1} I_{3}$ for nonane and $I \cdot 19$ for decane. 
Table I. Patterns of paraffin utilization in the wild-type and mutant strains of Mycobacterium rhodochrous

No. indicates the number of mutants of each type obtained. Frequency indicates the $\%$ of mutants of each type among the tested colonies obtained from penicillin enrichment, following u.v. irradiation.

\begin{tabular}{|c|c|c|c|c|c|c|c|c|c|c|c|c|c|c|}
\hline & \multicolumn{12}{|c|}{$n$-Paraffin (no. of carbon atoms) } & \multirow[b]{2}{*}{ No. } & \multirow{2}{*}{$\begin{array}{l}\text { Fre- } \\
\text { quency } \\
(\%)\end{array}$} \\
\hline & 8 & 9 & IO & I I & 12 & I3 & I4 & I5 & I6 & 17 & I 8 & $19-28$ & & \\
\hline $\begin{array}{l}\text { B29 } \\
\text { (wild-type) }\end{array}$ & + & + & + & + & + & + & + & + & + & + & + & + & & \\
\hline Type A & - & + & + & + & + & + & + & + & + & + & + & + & I & 0.23 \\
\hline Type B & - & - & + & + & + & + & + & + & + & + & + & + & 13 & $*$ \\
\hline Type C & - & - & - & + & + & + & + & + & + & + & + & + & 3 & 0.06 \\
\hline Type D & - & - & - & - & + & + & + & + & + & + & + & + & $n$ & 35 \\
\hline Type E & - & - & - & - & - & + & + & + & + & + & + & + & 8 & 0.15 \\
\hline Type F & - & - & - & - & - & - & + & + & + & + & + & + & 2 & 0.04 \\
\hline Type G & - & - & - & - & - & - & - & - & - & - & - & + & 8 & 0.15 \\
\hline Type H & + & + & + & - & - & + & + & + & + & + & + & + & I & 0.02 \\
\hline Type I & - & - & - & - & - & + & + & - & - & - & - & - & I & 0.02 \\
\hline Type J & - & - & - & - & - & - & - & - & - & - & - & - & 7 & 0.13 \\
\hline
\end{tabular}

\section{DISCUSSION}

The existence of stable mutants of Mycobacterium rhodochrous with modified patterns of $n$-paraffin utilization implies that the metabolism of $n$-paraffins in this species is under the control of several mutable genetic sites. It is known that for several of the reactions involved in $n$-paraffin metabolism, e.g. paraffin hydroxylation (McKenna \& Coon, 1970) and fatty acid activation (Trust \& Millis, I970 b; Trust \& Millis, 197I), enzymes exist which are active only over a certain range of carbon chain lengths. One possible explanation for the behaviour of some of the mutants is the impairment of an enzyme of this type.

In several bacterial species (Cardini \& Jurtshuk, 1970; Gholson, Baptist \& Coon, 1963) $n$-octane appears to be metabolized via I-octanol, octanal and octanoic acid. Since mutants of types A to I are all capable of utilizing these intermediates as sole carbon source, the mutational defect must lie in octanol synthesis. This fact, coupled with the unimpaired $n$-octane hydroxylating activity of cell-free extracts of M35, implies that in this strain, at least, the inability to grow on $n$-octane is due either to a transport defect or to the failure of octane, but not of nonane or decane, to induce the hydroxylase.

Little is known of the mechanisms by which bacteria are able to metabolize a wide range of $n$-paraffins. In particular, there is inadequate information on the range of substrate specificity for each of the enzymes participating in $n$-paraffin metabolism. Mutants such as those described above should prove useful tools in the elucidation of these mechanisms.

Permission to publish this paper has been given by The British Petroleum Company Limited. 


\section{REFERENCES}

Cardini, G. \& JURTShuk, P. (1970). The enzymatic hydroxylation of $n$-octane by Corynebacterium sp. Strain 7EIC. Journal of Biological Chemistry 245, 2789-2796.

DAvis, B. D. (I949). The isolation of biochemically deficient mutants of bacteria by means of penicillin. Proceedings of the National Academy of Sciences of the United States of America 35, 1-10.

FosTER, J. W. (1962). Hydrocarbons as substrates for microorganisms. Antonie van Leeuwenhoek 28, 24 I-274.

Fredricks, K. M. (1967). Products of the oxidation of $n$-decane by Pseudomonas aeruginosa and $M y c o-$ bacterium rhodochrous. Antonie van Leeuwenhoek 33, 4I-48.

Gholson, R. K., BaPtist, J. N. \& Coon, M. J. (1963). Hydrocarbon oxidation by a bacterial enzyme system. II. Cofactor requirements for octanal formation from octane. Biochemistry 2, I I 55-I I 59 .

IIZUKA, H., IIDA, M., UNAMI, Y. \& Hoshino, Y. (I968). $n$-Decane dehydrogenation by a cell-free extract of Candida rugosa. Zeitschrift für Allgemeine Mikrobiologie 8, I45-149.

Lowry, O. H., Rosebrough, N. J., Farr, A. L. \& Randall, R. J. (I95I). Protein measurement with the Folin phenol reagent. Journal of Biological Chemistry 193, 265-275.

MCKenna, E. J. \& Coon, M. J. (I970). Enzymatic $\omega$-oxidation. IV. Purification and properties of the $\omega$ hydroxylase of Pseudomonas oleovorans. Journal of Biological Chemistry 245, 3882-3889.

TRUST, T. J. \& Millis, N. F. (I970a). The isolation and characterization of alkane-oxidizing organisms and the effect of growth substrate on isocitrate lyase. Journal of General Microbiology 6r, 245-254.

Trust, T. J. \& Millis, N. F. $(1970 b)$. Activation of the $\mathrm{C}_{1}$ to $\mathrm{C}_{14}$ monocarboxylic acids by a yeast. Journal of Bacteriology ro4, I397-I398.

Trust, T. J. \& Millis, N. F. (197I). Activation of the $\mathrm{C}_{2}$ to $\mathrm{C}_{19}$ monocarboxylic acids by Pseudomonas. Journal of Bacteriology 105, I 2 I 6-I 218. 